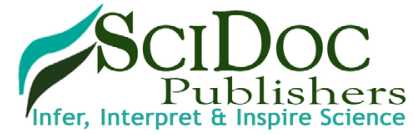

\section{miRNAs Expression Profiling, An Exploratory Method for Revealing First-Hand Biomarkers to Predict Disease Progression}

Editorial

Islam SMR

Assistant Professor, Department of Virology, Bangabandhu Sheikh Mujib Medical University (BSMMU), Dhaka, Bangladesh.

Molecular techniques has proven to be a powerful tool to identify reliable predictors of treatment response or disease progression detection and early prediction. Different body cell possess various host expression profiles, and has its own specific indicators to identify different diseases/infection class. Analyzing microRNAs (miRNAs) as a promising host gene plays a critical roles in host interactions with various invaders, including their pathogenesis and host resistance through regulation of post-transcriptional translation or gene expression of related miRNAs, thus acting as a potential biomarkers of infectious diseases. Circulating miRNAs have great potential to facilitate the diagnosis of virus infection, although the discrepancy between the expression levels of intracellular and extracellular miRNAs, that has been observed in certain situations [1]. Circulating miRNAs were found to be extremely stable and protected from RNAse mediated degradation within the body fluids, therefore have emerged as candidate biomarkers for several illnesses [2].

In 1993, miRNAs were discovered in the course of an experiment in the nematode; Caenorhabditis elegans (C. elegans) [3]. Until now, human miRNA family has expanded near to 2000 mature miRNAs (miRBase v21.0; http:/ / www.mirbase.org) with approximately $60 \%$ of human mRNA could be the targets of miRNA [4]. miRNAs constitutes about 18-22 nucleotides long noncoding RNAs, and playing a vital role in the regulation of gene expression. The production of miRNAs requires some processing phases. Firstly, primary miRNAs (pri-miRNAs) are cleaved by aribo nuclease, called Drosha to produce a precursor miRNAs (premiRNAs) which eventually, cleaved by the another ribo nuclease, termed Dicerto produce mature, single stranded miRNAs [5, 6]. At this stages, mature miRNA associate with RNA induced silencing complex (RISC) with Argonaute/EIF2C (AGO) proteins which recognizes their respective target mRNA. miRNA identify their target mRNA through specificbase-pairing interactions between the 5' end (termed as "seed"region) of miRNA and a sites within the coding and untranslated regions (UTRs) especially 3' UTR of mRNAs leading to mRNA destabilization. Thus, miR-
NAs inhibits the target gene expression either by mRNA degradation or translational repression [7,8]. A distinctive nature of miRNAs regulation is that, each miRNA regulates hundreds of different mRNAs, whereas, a single mRNAs are targeted by multiple miRNAs, that are the focus of interest on regulatory networks that determine the cell fate decisions [9].

miRNAs involvement in cancer was first described in 2002 for its regulation in leukemia [10]. While the predictive value might get different among individual miRNAs and expression profiles involvement of multiple miRNAs were expected to play a useful role in tumor classification, diagnosis, and prognosis [11]. It is also thought to be a promising candidate for the next generationdiagnostic biomarkers because of the strong correlation between miRNAs expression patterns and disease status [12,13]. The level of circulating miRNA is quite stable in healthy people, but deregulated under certain situations, like physiological changes, inflammation, and cell death [14]. Moreover, profiling of circulating miRNAs may also be utilized for an extended study any association with the mechanism of pathogenesis, tissue damage or cell to cell communications [15]. In addition, circulating miRNAs resist harsh conditions, including RNase digestion, freeze-thawing, boiling, and extreme $\mathrm{pH}$ conditions, allowing them to be a promising markers for the non-invasive detection of various diseases [16]. miRNAs stability in body fluids make it a potential marker for sensitive detection by quantitative PCR and non-invasiveness in obtaining samples of body fluids [17].

To serve as a reliable biomarker, standardized methods for serum miRNAs determinations often required. Many methods exist for isolating RNA from serum but accurate measurement of serum miRNAs is challenging due to the low quantity, short length, and high sequence variability [18]. The starting quality of RNA is critical for accurate miRNAs quantification and these circulating miRNAs can be identified in both serum and plasma [19]. Occasionally, a large volume of initial plasma/serum were taken to get the preferable RNA yield for quality down-stream molecular

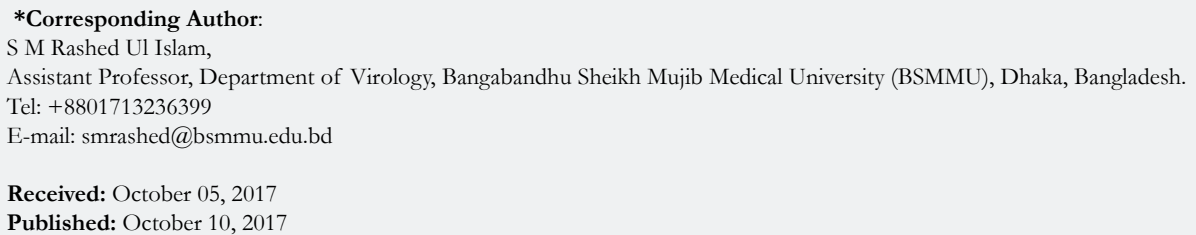

Copyright: Islam SMR $^{\circ}$ 2017. This is an open-access article distributed under the terms of the Creative Commons Attribution License, which permits unrestricted use, distribution and reproduction in any medium, provided the original author and source are credited. 
analysis [13]. For an effective miRNAs host gene profiling, a good quality control approach with experienced expertise thoughts are required for a successful technical application analysis. Using anticoagulants during blood collection, EDTA is preferable over citrate and heparin. As both citrate and heparin have an inhibitory effects on real-time PCR as well as next-generation sequencing (NGS) [20]. Archived plasma samples are often discouraged for biomarker identification and significant variation of miRNAs expression in plasma may be contributed by blood-cell specific and platelet specific miRNAs from hemolysis [21].

To get a good miRNAs yield and purity, several extraction process involving phenol-chloroform, guanidinium thiocyanate, ethanol or Silica-based miRNA recovery are employed. But the choice remains to the specific methodology for miRNA extraction from plasma and body fluids depends mainly on initial sample input, techniques of analysis or target spectrums of miRNA species in relation to diseases [22]. For selecting an ultimate analyzing tools, NGS, microarray, and real-time PCR are the methods used to measure miRNAs abundance in expression profiling studies. Though, NGS is not yet practical for serum miRNAs profiling studies due to the requirement of significantly larger RNA input [14] rather, it required by miRNA microarrays is comparable to real-time PCR [23]. However, microarrays offer less sensitivity and require significantly more struggle for data processing when compared with real-time PCR platforms. Thus, real-time PCR is the most commonly used approach in high-throughput expression profiling and quantification [24]. Until today, NGS are the most promising technology for miRNAs profiling and several advantages have been already elaborated elsewhere [21]. Specifically, NGS is extremely sensitive method which also allow a relative quantification and it is capable of differentiating isomiRs from miRNAs [25]. But, the most profound importance of NGS approach to detect and verify novel miRNAs and gene to be get accepted including strong description of its size and structural identity [26]. Though, a very high cost and limited support of computational infrastructure and bioinformatics often discourages its utilizations [22].

miRNAs analysis requires additional quality control and normalization steps that remain unstandardized [27]. Relative quantification is the most common strategy to assess RNA expression differences between two samples. An endogenous control is routinely included with sample input volume for expression normalization $[13,28]$. However, the applicability of an endogenous miRNA control may be influenced by disease or treatment creating a biased calculation [29, 30]. Therefore, an extraction control, synthetic C. elegansmi RNA spike-ins have been used in serum biomarker normalization with much confidence [13].

There are many gaps found on miRNAs findings interpretations, including regulation of miRNA production, specific targets, and mechanisms of active secretion [31]. As for example, circulating liver-specific miRNA-122 was found to be up-regulated on liver injury [28, 32, 33]; whereas, significantly down-regulated during late-stage hepatic cirrhosis [34] and hepatocellular carcinoma [35] due to intracellular down-regulation of miRNA production. Therefore, levels of certain circulating miRNAs may be significantly up-regulated during acute phases, or down-regulated thereafter. Another problem, which might provide an additional difficulty is that most published researchers have designed their experiments to compare a disease group with a healthy group, rather than including an alternative disease groups. A biomarker may strongly discriminate between a disease group and a healthy group but may also prove to pay an impact with another disease [36]. Therefore, inclusion of an alternate group during the study might solve the issues. Another challenge to the use of miRNAs as markers is that their mRNA targets are not easily identified by computational methods [37] and levels of miRNAs in whole blood are much higher than plasma or serum miRNAs levels [38]. Hence, levels of specific miRNAs in different body fluids were not readilyfound comparable [39].

Regarding a technical challenge, there is no standardized method for profiling miRNAs found in many published articles. Importantly, sample type, processing, extraction methods etc. vary among reports, and information on the starting fluid volume and particularly the efficiency of extraction were often missing. Investigators may make this information available for easy standardizations and perhaps compare profiles across various patient cohorts [22].

Finally, this editorial tried to describe the potent role of miRNAs as a pertinent host gene that might provide earlier warning signs in various disease prediction, resulting in more effective treatment and improve survival. Thus, multi-center studies with cross-validation are required to generate miRNAs as novel biomarkers as a new diagnostics of diseases.

\section{References}

[1]. Elhelw DS, Mekky RY, El-Ekiaby N, Ahmed R, Eldin MAM, El-Sayed M, et al. Predictive prognostic role of miR-181 with discrepancy in the liver and serum of genotype 4 hepatitis C virus patients. Biomed Rep. 2(6):843-8. PubMed Central PMCID: 4179737.

[2]. Blanco-Calvo M, Calvo L, Figueroa A, Haz-Conde M, Antón-Aparicio L, Valladares-Ayerbes M. Circulating MicroRNAs: Molecular microsensors in gastrointestinal cancer. Sensors. 2012;12(7):9349-62. PubMed PMID:23012546.

[3]. Lee RC, Feinbaum RL, Ambros V. The C. elegans heterochronic gene lin-4 encodes small RNAs with antisense complementarity to lin-14. Cell. 1993 Dec 3;75(5): 843-54. PubMed PMID:8252621.

[4]. Friedman RC, Farh KKH, Burge CB, Bartel DP. Most mammalian mRNAs are conserved targets of microRNAs. Genome Res. 2009 Jan;19(1):92-105. PubMed PMID: 18955434.

[5]. Meister G, Tuschi T. Mechanisms of gene silencing by double-stranded RNA. Nature. 2004 Sep 16;431(7006):343-9. PubMed PMID: 15372041.

[6]. Bartel DP. MicroRNAs: Target Recognition and Regulatory Functions. Cell. 2009 Jan 23;136(2):215-33. PubMed PMID: 19167326.

[7]. Filipowicz W, Bhattacharyya SN, Sonenberg N. Mechanisms of post-transcriptional regulation by microRNAs: are the answers in sight? Nat Rev Genet. 2008 Feb; 9(2):102-14. PubMed PMID: 18197166.

[8]. Winter J, Jung S, Keller S, Gregory RI, Diederichs S. Many roads to maturity: microRNA biogenesis pathways and their regulation. Nat Cell Biol. NAt cell Biol. 2009 Mar;11(3):228-34. PubMed PMID: 19255566.

[9]. Roberts AP, Lewis AP, Jopling CL. The role of microRNAs in viral infection. Prog Mol Biol Transl Sci. 2011;102:101-39. PubMed PMID: 21846570.

[10]. Calin GA, Dumitru CD, Shimizu M, Bichi R, Zupo S, Noch E, et al. Nonlinear partial differential equations and applications: Frequent deletions and down-regulation of micro- RNA genes miR15 and miR16 at $13 \mathrm{q} 14$ in chronic lymphocytic leukemia. Proc Natl Acad Sci. 99(24):15524-9.

[11]. Hayes NC, Chayama K. Micrornas as biomarkers for liver disease and hepatocellular carcinoma. Int J Mol Sci. 2016 Feb 24;17(3):280. PubMed PMID: 26927063.

[12]. Moussay E, Wang K, Cho J-H, van Moer K, Pierson S, Paggetti J, et al MicroRNA as biomarkers and regulators in B-cell chronic lymphocytic leukemia. Proc Natl Acad Sci. 2011 Apr 19. 108(16):6573-8. PubMed Central PMID: PMC3081030.

[13]. Mitchell PS, Parkin RK, Kroh EM, Fritz BR, Wyman SK, Pogosova-Agadjanyan EL, et al. Circulating microRNAs as stable blood-based markers for cancer detection. Proc Natl Acad Sci. 2008 Jul 29;105(30):10513-8. 
[14]. Chen X, Ba Y, Ma L, Cai X, Yin Y, Wang K, et al. Characterization of microRNAs in serum: a novel class of biomarkers for diagnosis of cancer and other diseases. Cell Res. 2008 Oct;18(10):997-1006. PubMed 18766179

[15]. Shwetha S, Gouthamchandra K, Chandra M, Ravishankar B, Khaja MN, Das S. Circulating miRNA profile in HCV infected serum: novel insight into pathogenesis. Sci Rep. 2013;3(1):1555. PubMed PMID: 23549102.

[16]. Weber JA, Baxter DH, Zhang S, Huang DY, Huang KH, Lee MJ, et al. The microRNA spectrum in 12 body fluids. Clin Chem. 2010 Nov;56(11):173341. PubMed PMID: 2087327. PubMed PMID: 20847327.

[17]. Etheridge A, Lee I, Hood L, Galas D, Wang K. Extracellular microRNA: A new source of biomarkers. Mutat Res. 2011 Dec 1;717(1-2):85-90. PubMed PMID:21402084.

[18]. Taylor CJ, Satoor SN, Ranjan AK, Pereira E Cotta M V, Joglekar MV. A protocol for measurement of noncoding RNA in human serum. Exp Diabetes Res. 2012;2012:168368. PubMed PMID: 22811698.

[19]. Kosaka N, Iguchi H, Ochiya T. Circulating microRNA in body fluid: A new potential biomarker for cancer diagnosis and prognosis. Cancer Science. 2010 Oct;101(10); 2087-92. PubMed PMID: 20624164.

[20]. Moldovan L, Batte K, Wang Y, Wisler J, Piper M. Analyzing the circulating microRNAs in exosomes/extracellular vesicles from serum or plasma by qRTPCR. Methods Mol Biol. 2013;1024:129-45. PubMed PMID: 23719947.

[21]. Pritchard CC, Kroh E, Wood B, Arroyo JD, Dougherty KJ, Miyaji MM, et al. Blood cell origin of circulating microRNAs: a cautionary note for cancer biomarker studies. Cancer Prev Res (Phila). 2012 Mar;5(3):492-7.

[22]. Moldovan L, Batte KE, Trgovcich J, Wisler J, Marsh CB, Piper M. Methodological challenges in utilizing miRNAs as circulating biomarkers. J Cell Mol Med. 18(3):371-90. PubMed PMID: 24533657.

[23]. Zhao H, Shen J, Medico L, Wang D, Ambrosone CB, Liu S. A pilot study of circulating miRNAs as potential biomarkers of early stage breast cancer. PLoS One. 2010 Oct 29; 5(10): e1375.

[24]. Li Y, Kowdley KV. Method for microRNA isolation from clinical serum samples. Anal Biochem. 431(1):69-75. PubMed PMID: 22982505.

[25]. Lee LW, Zhang S, Etheridge A, Ma L, Martin D, Galas D, et al. Complexity of the microRNA repertoire revealed by next-generation sequencing. RNA. 2010 Nov;16(11):2170-80. PubMed PMID: 20876832.

[26]. Pang KC, Stephen S, Dinger ME, Engstrm PG, Lenhard B, Mattick JS. RNAdb 2.0 - An expanded database of mammalian non-coding RNAs. Nucleic Acids Res. 2007 Jan;35:D172-82. PubMed PMID: 17145715.

[27]. Natarajan SK, Pachunka JM, Mott JL. Role of microRNAs in alcohol-induced multi-organ injury. Biomolecules. 2015 Nov 20;5(4):3309-38. PubMed PMID: 26610589.
[28]. Qi P, Cheng S, Wang H, Li N, Chen Y, Gao C. Serum MicroRNAs as Biomarkers for Hepatocellular Carcinoma in Chinese Patients with Chronic Hepatitis B Virus Infection. PLoS One. 6(12):e28486. PubMed PMID: 22174818.

[29]. Bihrer V, Waidmann O, Friedrich-Rust M, Forestier N, Susser S, Haupenthal J, et al. (2011) Serum microRNA-21 as marker for necroinflammation in hepatitis $\mathrm{C}$ patients with and without hepatocellular carcinoma. PLoS One. 2011;6(10): e26971. PubMed PMID: 22066022.

[30]. Song J, Bai Z, Han W, Zhang J, Meng H, Bi J, et al. Identification of suitable reference genes for qPCR analysis of serum microRNA in gastric cancer patients. Dig Dis Sci. 2012 Apr;57(4):897-904. PubMed PMID: 22198701.

[31]. Mas VR, Dumur CI, Scian MJ, Gehrau RC, Maluf DG. MicroRNAs as biomarkers in solid organ transplantation. Am J Transplant. 2013 Jan13;13(1):11-9. PubMed Central PMCID: 3927320.

[32]. Xu J, Wu C, Che X, Wang L, Yu D, Zhang T, et al. Circulating MicroRNAs, miR-21, miR-122, and miR-223, in patients with hepatocellular carcinoma or chronic hepatitis. Mol Carcinog. 2011 Feb;50(2):136-42. PubMed PMID: 21229610.

[33]. Anadol E, Schierwagen R, Elfimova N, Tack K, Schwarze-Zander C, Eischeid $\mathrm{H}$, et al. Circulating microRNAs as a marker for liver injury in human immunodeficiency virus patients. Hepatology. 61(1):46-55.

[34]. Trebicka J, Anadol E, Elfimova N, Strack I, Roggendorf M, Viazov S, et al Hepatic and serum levels of miR-122 after chronic HCV-induced fibrosis. J Hepatol. 2013 Fen;58(2):234-9. PubMed PMID: 23085648.

[35]. Tan Y, Ge G, Pan T, Wen D, Chen L, Yu X, et al. A serum microRNA panel as potential biomarkers for hepatocellular carcinoma related with hepatitis B virus. PLoS One. 2014 Sep 19;9(9):e107986. PubMed PMID: 25238238.

[36]. Haider BA, Baras AS, McCall MN, Hertel JA, Cornish TC, Halushka MK. A critical evaluation of microRNA biomarkers in non-neoplastic disease. PLoS One. 2014 Feb 26;9(2):e89565. PubMed PMID: 24586876.

[37]. McDonald JS, Milosevic D, Reddi HV, Grebe SK, Algeciras-Schimnich A. Analysis of circulating microRNA: Preanalytical and analytical challenges. Clin Chem. 2011 Jun;57(6):833-40. PubMed PMID: 21487102.

[38]. Heneghan HM, Miller N, Lowery AJ, Sweeney KJ, Newell J, Kerin MJ. Circulating microRNAs as Novel Minimally Invasive Biomarkers for Breast Cancer. Ann Surg. 2010 Mar; 251(3):499-505. PubMed PMID:20134314.

[39]. Albulescu R, Neagu M, Albulescu L, Tanase C. Tissular and soluble miRNAs for diagnostic and therapy improvement in digestive tract cancers. Expert Rev Mol Diagn. 2011 Jan;11(1):101-20. 